\title{
A Male Patient Showing Abnormal Gait and Dysarthria with Psychotic Symptoms
}

Anormal Yürüyüş ve Psikotik Semptomlarla Birlikte Dizartri ile Prezente Bir Erkek Hasta

\author{
(1) Eu Jene Choi1 , (1) Dong Goo Lee², (1) Changxu Cui3 \\ 1 Ulsan University Hospital, Ulsan University College of Medicine, Department of Neurology, Ulsan, Republic of Korea \\ 2The University of British Columbia Faculty of Medicine, Department of Neurology, Vancouver, Canada \\ ${ }^{3}$ Life Commune Shimousanakayama, Kinoshita Elderly Care Ltd, Chiba, Japan
}

\begin{abstract}
Pantothenate kinase-associated neurodegeneration (PKAN) is a rare autosomal-recessive and neurodegenerative disorder associated with progressive motor impairment and mental deterioration. The diagnosis of PKAN consists of clinical features and magnetic resonance imaging (MRI) evidence of iron accumulation in the brain, as well as evidence of mutations in the pantothenate kinase 2 (PANK2) gene. Typical clinical features of PKAN are motor symptoms including dystonia, involuntary movement, rigidity and dysarthria, as well as psychiatric symptoms such as anxiety, depression, and mental retardation. However, psychosis has not been reported often in cases of PKAN. This patient presented with anxiety, a tendency to startle easily, and rapidly deteriorating memory impairment. T2-weighted MRI of his brain indicated a specific pattern of hyperintensity within a hypointense medial globus pallidus with a mutation in the gene encoding PANK2. Components of the basal ganglia, including the globus pallidus, play a key role in motor symptoms, cognition, affect, and mood. The basal ganglia are also a central factor in the pathogenesis of psychiatric symptoms in schizophrenia. These lesions are able to aggravate various psychotic symptoms, cognitive function impairments, and mood disorders because PKAN is affected by abnormal iron deposition in the globus pallidus and substantia nigra pars reticulata.
\end{abstract}

Keywords: Pantothenate kinase-associated neurodegeneration, psychosis, neurodegenerative diseases

Öz

Pantotenat kinaz ile ilişkili nörodejenerasyon (PKAN), progresif motor bozukluk ve zihinsel bozulma ile ilişkili nadir bir otozomal resesif ve nörodejeneratif bozukluktur. PKAN tanısı, klinik bulgular ve beyindeki demir birikiminin manyetik rezonans görüntüleme (MRG) ile gösterilmesinin yanı sıra pantotenat kinaz 2 (PANK2) genindeki mutasyonların gösterilmesi ile konur. PKAN'nin tipik klinik özellikleri distoni, istemsiz hareketler, rijidite ve dizartri gibi motor semptomların yanı sıra anksiyete, depresyon ve zihinsel gerilik gibi psikiyatrik semptomlardır. Bununla birlikte, PKAN'li hastalarda psikoz sıklıkla bildirilmemiştir. Bildirdiğimiz hasta, anksiyete, kolayca irkilme eğilimi ve hızla ilerleyen hafıza bozukluğu ile başvurdu. Beyninin T2 ağırlıklı MRG’sinde spesifik bir bulgu olarak hipointens medial globus pallidus içinde hiperintens bir görünüm saptandı ve hastada PANK2'yi kodlayan gende mutasyon tespit edildi. Globus pallidus da dahil olmak üzere bazal gangliyonların bileşenleri, motor semptomlar, biliş, duygulanım ve duygudurum üzerinde anahtar bir rol oynar. PKAN'de görülen globus pallidus ve substantia nigra pars retikulatadaki anormal demir birikimi çeşitli psikotik semptomları, bilişsel işlev bozukluklarını ve duygudurum bozukluklarını şiddetlendirebilir.

Anahtar Kelimeler: Pantotenat kinaza bağlı nörodejenerasyon, psikoz, nörodejeneratif hastalıklar

\section{Introduction}

Pantothenate kinase-associated neurodegeneration (PKAN) is a rare autosomal recessive condition involving neurodegeneration and iron accumulation in the brain. PKAN falls under the following categories: genetic disorder of iron and other pigment metabolism, neuroaxonal dystrophy, vitamin E deficiency, and ceroid storage disease (1). PKAN is also the most prevalent form of neurodegeneration with brain iron accumulation. These are a wide range of disorders with markedly excessive regional brain iron deposition, particularly in the

Address for Correspondence/Yazışma Adresi: Eu Jene Choi MD, Ulsan University Hospital, Ulsan University College of Medicine, Department of Neurology, Ulsan, Republic of Korea

Phone:+821076597582 E-mail:0734526@uuh.ulsan.kr ORCID: orcid.org/0000-0002-0826-6001

Received/Geliş Tarihi: 27.08.2019 Accepted/Kabul Tarihi: 23.01.2020

${ }^{\circ}$ Copyright 2020 by Turkish Neurological Society

Turkish Journal of Neurology published by Galenos Publishing House. 
cerebellar dentate nuclei as well as regions of the basal ganglia including globus pallidus, substantia nigra pars reticulata, and striatum $(2,3,4)$. PKAN is caused by mutations in the gene that encodes mitochondrial pantothenate kinase 2 (PANK2), which is a rate-determining enzyme in coenzyme $\mathrm{A}(\mathrm{CoA})$ biosynthesis $(5,6,7)$.

PKAN is characterized by the early onset of progressive movement alterations, including dystonia, rigidity, and choreoathetosis. Patients with PKAN may also present with a variety of psychiatric symptoms, primarily depression and mental deterioration (8). Additionally, magnetic resonance imaging (MRI) of patients with PKAN typically reveals the "eye of the tiger" sign (9). However, the diagnosis of PKAN is ultimately made through molecular genetic testing $(8,10)$.

Typically, patients with PKAN present in the first decade of life with dystonia, dysarthria, rigidity, and pigmentary retinal degeneration (3,11). Atypical cases of PKAN do not present until the second or third decade of life and progress more slowly than typical cases (3).

\section{Case Report}

Clinical History, Neurologic Examination, and Laboratory Findings

A 35-year-old Korean male had abdominal pain and abnormal posture of the trunk and lower extremities. He additionally complained of difficulty in walking and had demonstrated an ataxic and spastic gait since November 2015. He had four half-brothers with whom he shared a father. His mother's pregnancy and delivery of him were normal. His medical history was significant for hepatitis A viral infection. Speech problems were noted when he was a high school student and he showed poor academic performance despite regular school attendance. He was otherwise healthy until the age of 32 when he began to demonstrate difficulty maintaining balance while walking and abnormal posturing of the trunk, where he arched backwards. However, all abnormal movements disappeared while he was sleeping. He additionally exhibited dysarthria, anxiety, symptoms of social withdrawal, and depression.

His physical examination revealed a young male of average build. There was no detectable rigidity in any of the four extremities and normal tendon reflexes were present. The extensor plantar reflex was present bilaterally. Furthermore, he exhibited dystonic posturing of the lower extremities, trunk, and neck. No tremor or choreoathetotic movements were seen. His fundus examination, as well as his neurologic and other systemic examinations, were unremarkable. Routine laboratory evaluations were normal: his serum ceruloplasmin level was $24 \mathrm{mg} / \mathrm{dl}$ (normal: 15-30 $\mu \mathrm{g} / \mathrm{dl}$ ), his 24-hour urinary copper excretion was $10 \mu \mathrm{g} /$ day (normal: under 38-70 $\mu \mathrm{g} /$ day), his serum copper level was $105 \mu \mathrm{g} / \mathrm{dl}$ (normal: 64-134 $\mu \mathrm{g} / \mathrm{dl}$ ), and his peripheral blood films revealed no acanthocytes.

Neuroradiologic, Neuropsychological, and Genetic Test Findings

$\mathrm{He}$ was evaluated using (18F) (3-fluoropropyl)-2 $\beta$ carbomethoxy-3 $\beta$-(4-iodophenyl)nortropane positron emission tomography (FP-CIT PET), (18F) fludeoxyglucose (FDG) PET, brain 1.5 T MRI, as well as neuropsychological tests. MR imaging revealed a prominent $\mathrm{T} 2$ dark signal intensity in the internal capsule bilaterally and definite hyperintense changes of the anterior medial portion of both globus pallidi. There were also focal encephalomalacic changes in each frontal lobe base (Figures $1,2 \mathrm{a}, 2 \mathrm{~b}, 2 \mathrm{c}, 3 \mathrm{a}, 3 \mathrm{~b}, 3 \mathrm{c})$.

(18F) FP-CIT PET showed symmetric and even striatal dopamine transporter binding. Visual inspection of the $(18 \mathrm{~F})$ FDG-PET images indicated no significant hyper-or hypometabolic activity in the brain (Figures $4 \mathrm{a}, 4 \mathrm{~b}, 5 \mathrm{a}, 5 \mathrm{~b}, 5 \mathrm{c}$ ). Statistical parametric mapping revealed definite hypometabolic areas in the putamen, caudate nucleus, and frontal gyrus $(\mathrm{p}<0.05$, FDR corrected, 100-voxel level, one sample t-test) (Figure 6a, 6b, 6c).

His mini-mental state exam score was 26 out of 30 and he was oriented to time, place and person with alertness; however, his immediate memory was below normal and word fluency, as well as inhibitory control ability, were abnormal in the addenbrookes cognitive examination. Also, confrontational naming problems and dyscalculia were shown but these did not significantly influence his ability to perform activities of daily living. His Korean-Beck Depression score was 23 out of 63, suggestive of significant depression.

Genetic testing identified two mutations (Glu 180 Gly and Asp378 Gly) involving exons 1 and 3 in his PANK2 gene (Figure 7). These locations were the first mutations shown in this gene. Specifically, there were two alterations-c.539-561del and $1133 \mathrm{~A}>\mathrm{G}$-in exon 1 and 3 of the cDNA sequence. These alterations resulted in a loss of the gene's functional properties by changing one amino acid.

Informed consent was obtained in writing from the patient's family for the publication of this case report.

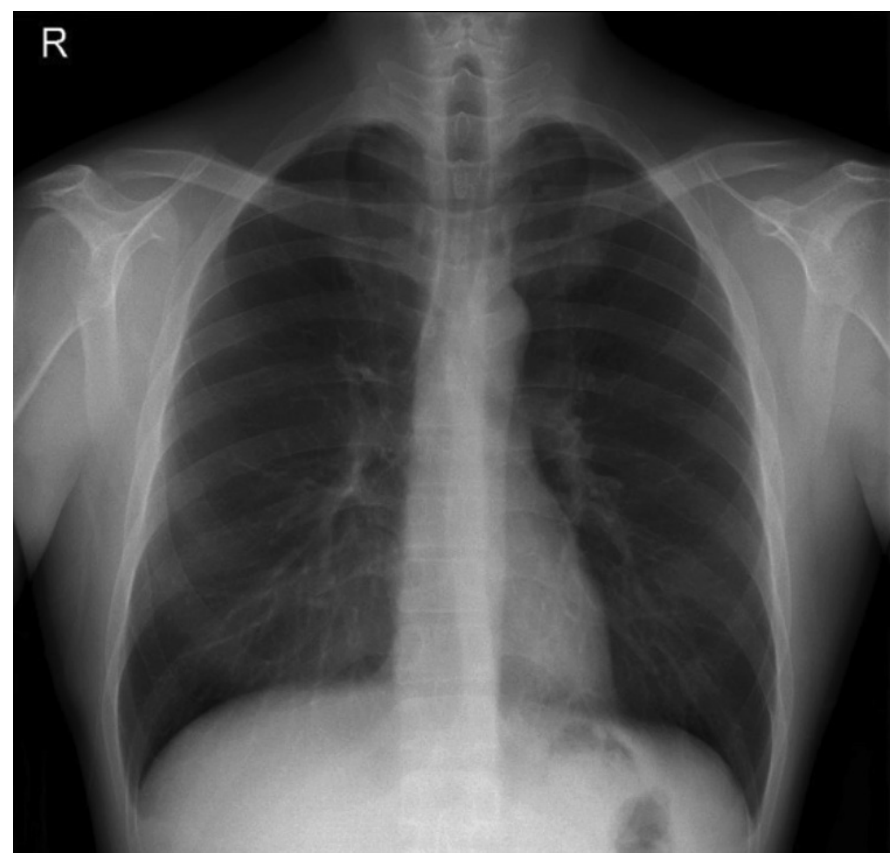

Figure 1. Non-specific findings in chest X-ray 


\section{Discussion}

Pantothenate kinase is an essential regulatory enzyme in CoA biosynthesis from pantothenate (vitamin B5); as such, pantothenate kinase facilitates the effectiveness of $\mathrm{CoA}$ as a central factor in intermediary and fatty acid metabolism. In PKAN, a deficiency of PANK2 is thought to result in mitochondrial accumulation of cysteine and cysteine-containing substrates, leading to rapid autooxidation in the presence of iron. This would result in free radical production and lipid peroxidation, and ultimately cell death. This male patient showed two mutations [c. (539-561del); (1133A>G)] [p. (Glu180Glyfs*42); (Asp378Gly)] from gene analysis for $P A N K 2$ and his brain MRI demonstrated bilateral hyperintensity within a region of hypointensity in the medial globus pallidus on T2-weighted and fluid attenuation inversion recovery images, named the "eye of the tiger" pattern. One of the mutations, c. (539-561del), might have been found for the first time in a Korean patient who was diagnosed as having PANK2. Homozygous, heterozygous, and compound heterozygous mutations in PANK2 have been previously identified, including deletions, insertions, nonsense, and missense mutations. PANK2 mutations in this patient generally resulted in premature protein termination. If we could perform genetic testing of his paternal relatives, it might allow us to understand the genetic origin of his disease.

Young-onset involuntary movements such as spinal myoclonus and multifocal dystonia, dysarthria and decreased intelligence, as well as psychotic symptoms, may lead us to investigate genetic movement disorders such as Wilson's disease or PKAN.
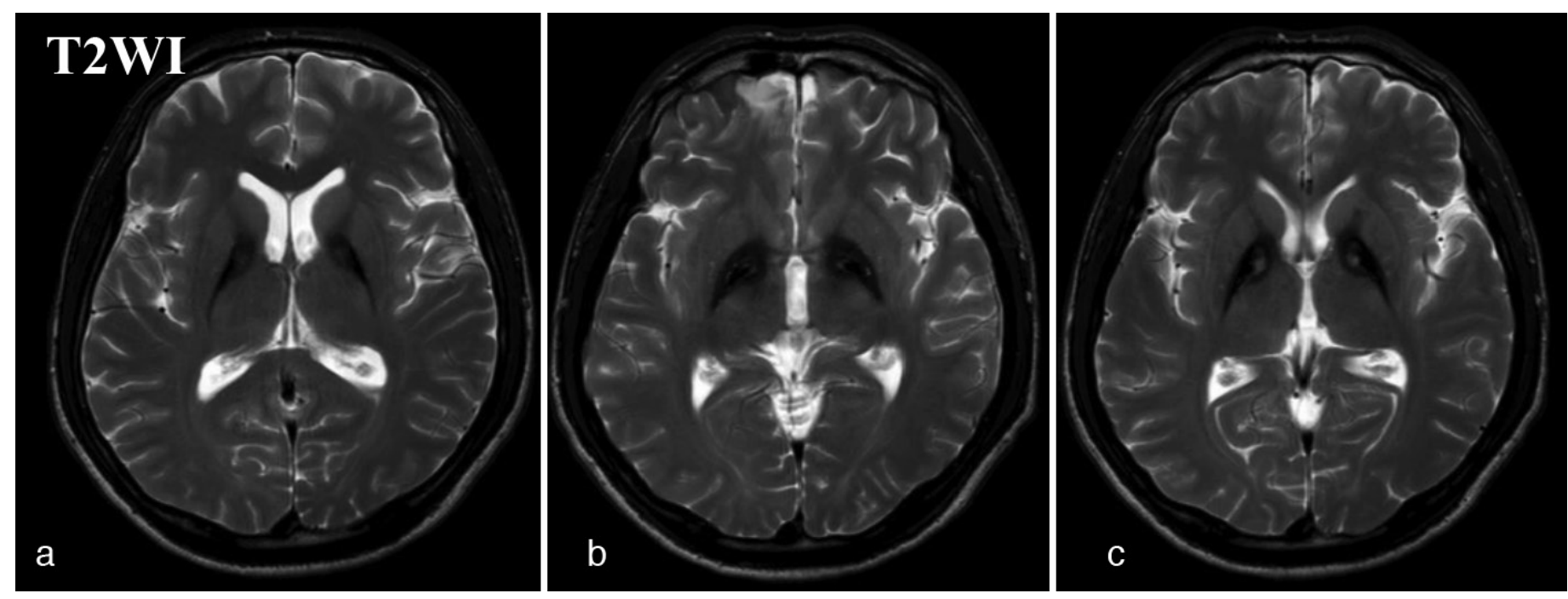

Figure 2. a, b, c) MR images depicted prominent T2 dark signal intensities in both internal capsules and definite hyperintensities in the anterior medial portion of both globus pallidi

MR: Magnetic resonance
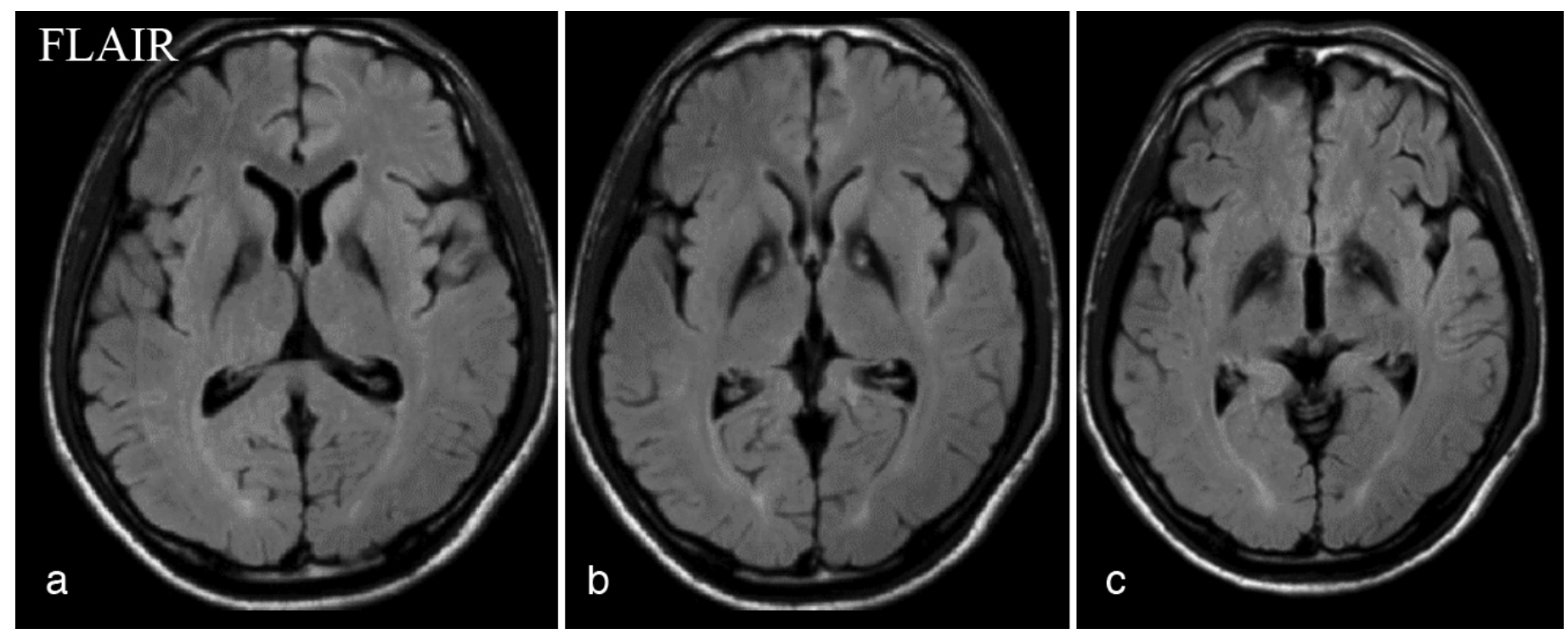

Figure 3. a, b, c) FLAIR MR images revealed dark signal intensities in both internal capsules and definite hyperintensities of the anterior medial portions of both globus pallidi

FLAIR: Fluid attenuation inversion recovery, MR: Magnetic resonance 


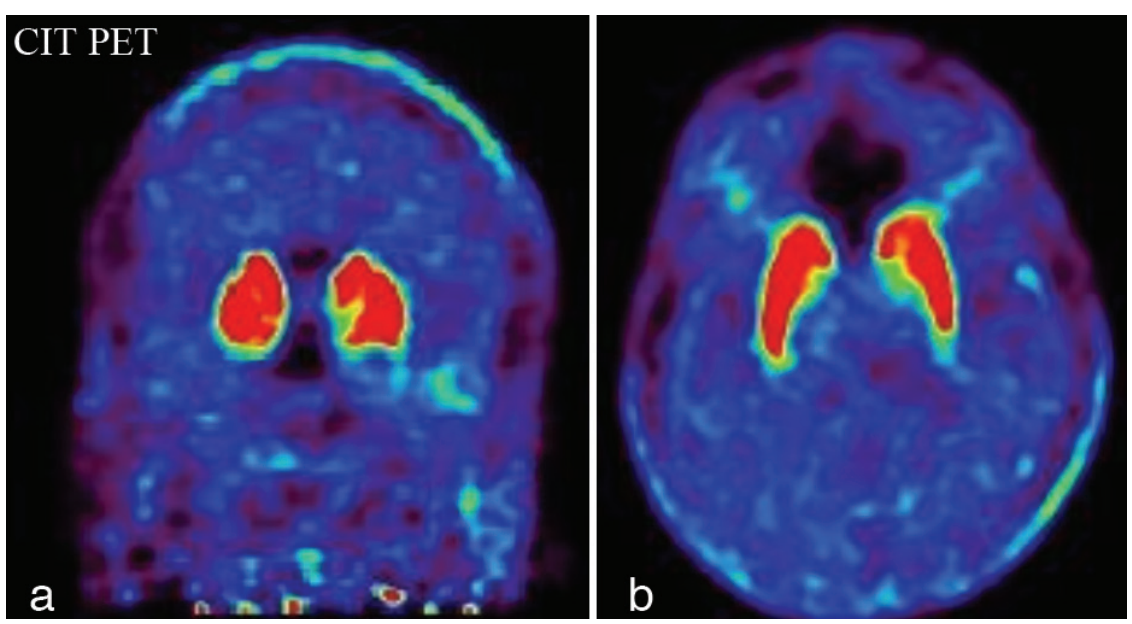

Figure 4. a, b) (18F) FP-CIT PET showed symmetric and even DAT binding of both striata despite his involuntary movements. In contrast, a patient with parkinsonism showed a marked loss of $\left({ }^{18} \mathrm{~F}\right)$ FP-CIT binding in putamen and caudate nucleus

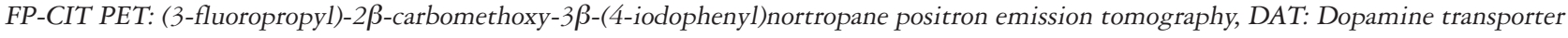
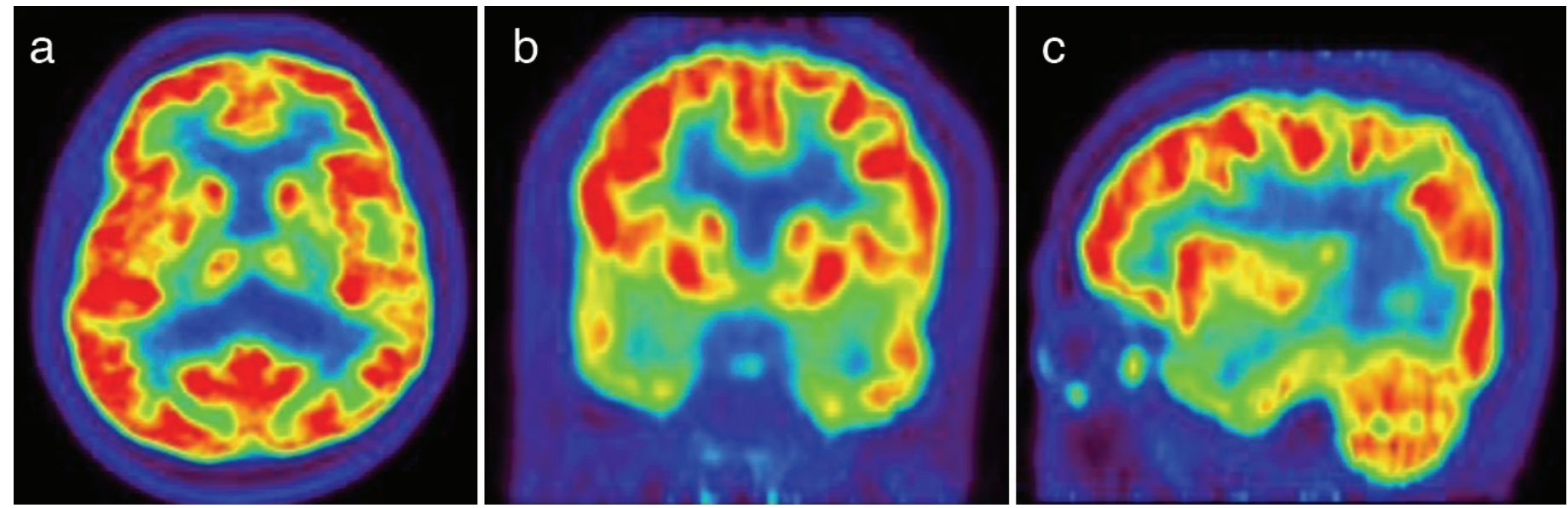

Figure 5. a, b, c) $\left.{ }^{18} \mathrm{~F}\right)$ FDG PET showed no significant findings compared with controls. Left: axial view, middle: coronal view, right: sagittal view FDG: Fludeoxyglucose, PET: Positron emission tomography
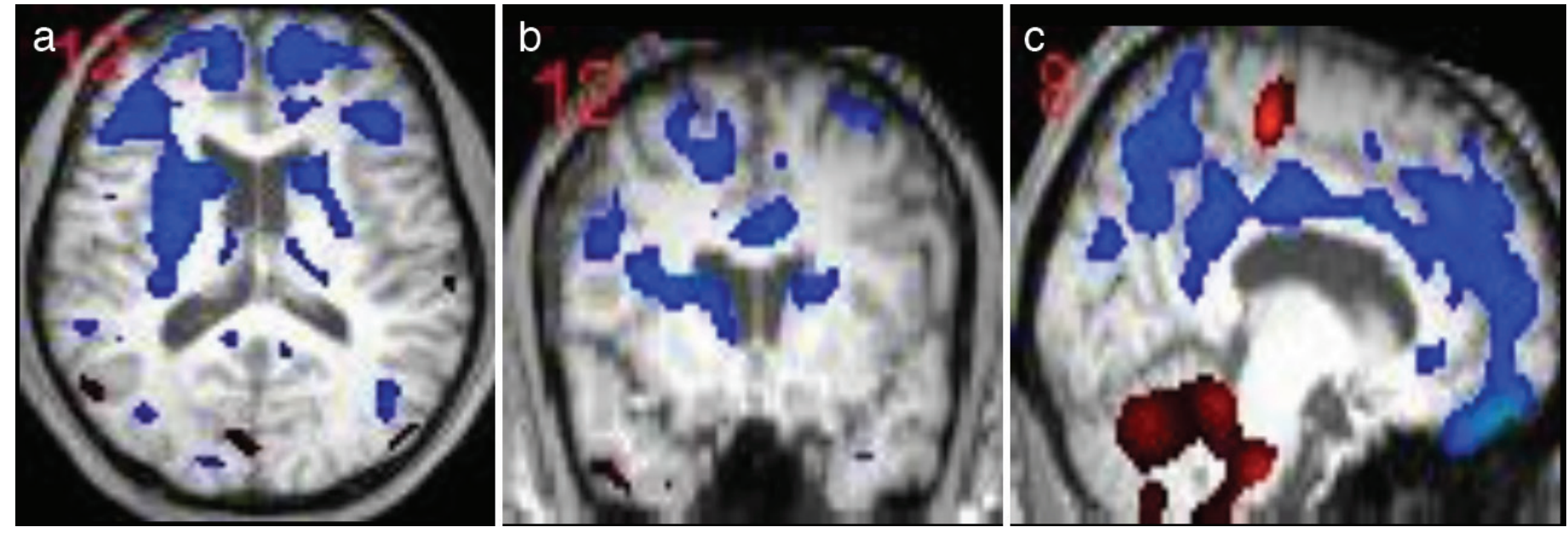

Figure 6. a, b, c) SPM analysis of (18F) FDG PET images revealed that the blue regions indicated significant hypo-metabolism compared with other brain regions ( $\mathrm{p}<0.05$, FDR corrected, 100-voxel level, one sample t-test), including bilateral putamen, caudate, inferior frontal gyrus (BA 47), middle frontal gyrus (BA 9), superior frontal medial gyrus (BA 8), cingulate gyrus and precuneus

SPM: Statistical parametric mapping, FDG: Fludeoxyglucose, PET: Positron emission tomography, FDR: False discovery rate 


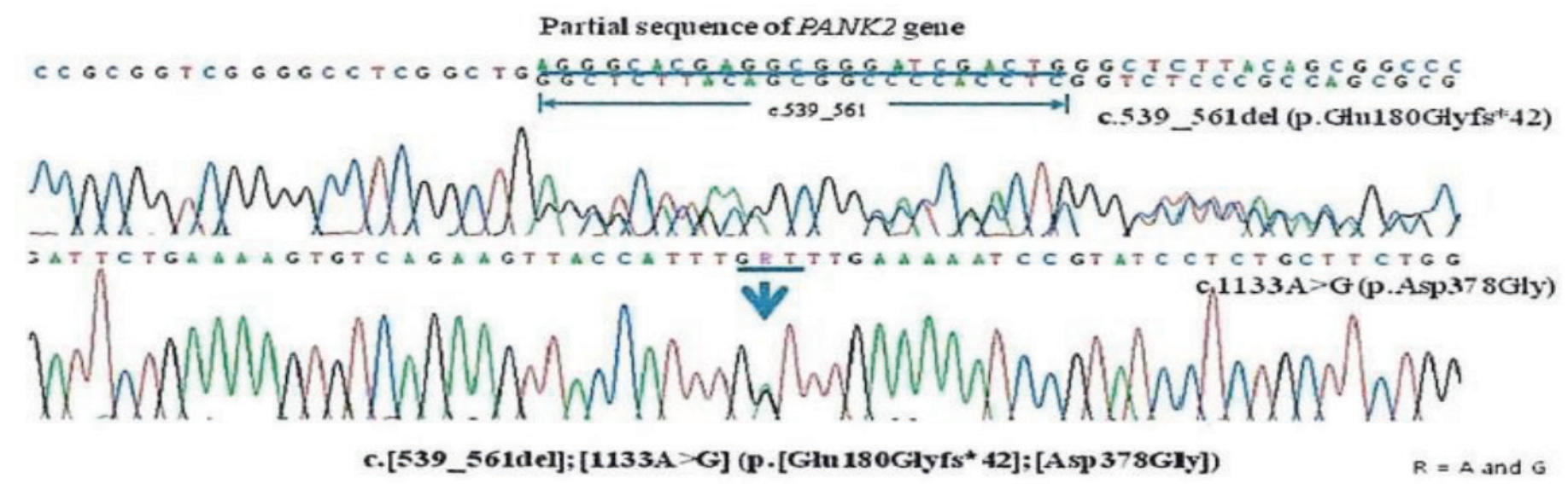

Figure 7. Gene analysis through PCR sequencing. Polymerase chain reaction (PCR) analysis of mutations using amplified DNA. Two mutations (Glu180 Gly and Asp378 Gly) involving exons 1 and 3 in the PANK2 gene of the patient were identified. Specifically, two alterations, c.539-561del and $1133 \mathrm{~A}>\mathrm{G}$, were found in exon 1 and 3 of the cDNA sequence, respectively. This resulted in the loss of functional properties by replacing one amino acid with another

\section{Acknowledgements}

The authors would like to thank the patient's family for allowing this case to be presented and further medical knowledge.

The authors performed the various roles for making this article. Mr. Dong Goo Lee performed the literature review, contributed to the introduction and revised the manuscript. Dr. Changxu Cui performed genetic analyses and contributed to the discussion. Prof. Eu Jene Choi collected the patient's history, performed the neurological examination, interpreted laboratory results and wrote the manuscript.

\section{Ethics}

Informed Consent: Informed consent was obtained in writing from the patient's family for the publication of this case report.

Peer-review: Externally peer-reviewed.

\section{Authorship Contributions}

Surgical and Medical Practices: E.J.C., Concept: E.J.C., Design: E.J.C., Data Collection or Processing: E.J.C., D.G.L., C.C., Analysis or Interpretation: C.C., E.J.C., Literature Search: D.G.L., C.C., E.J.G., Writing: D.G.L., C.C., E.J.G.

Conflict of Interest: No conflict of interest was declared by the authors.

Financial Disclosure: The authors declared that this study received no financial support.

\section{References}

1. Jankovic J, Kirkpatrick JB, Blomquist KA, Langlais PJ, Bird ED. Late-onset Hallervorden-Spatz disease presenting as familial Parkinsonism. Neurology $1985: 35: 227-234$
2. Dusek P, Schneider SA. Neurodegeneration with brain iron accumulation. Curr Opin Neurol 2012;25:499-506.

3. Leoni V, Strittmatter L, Zorzi G, et al. Metabolic consequences of mitochondrial coenzyme A deficiency in patients with PANK2 mutations. Mol Genet Metab 2012;105:463-471.

4. Ring HA, Serra-Mestres J. Neuropsychiatry of the basal ganglia. J Neurol Neurosurg Psychiatry 2002;72:12-21.

5. Haraguchi T, Terada S, Ishizu H, et al. Coexistence of TDP-43 and tau pathology in neurodegeneration with brain iron accumulation type 1 (NBIA-1, formerly Hallervorden-Spatz syndrome). Neuropathology 2011;31:531-539.

6. Chiapparini L, Savoiardo M, D'Arrigo S, et al. The "eye-of- the-tiger" sign may be absent in the early stages of classic pantothenate kinase associated neurodegeneration. Neuropediatrics 2011;42:159-162.

7. Delgado RF, Sanchez PR, Speckter H, et al. Missense PANK2 mutation without "eye of the tiger" sign: MR findings in a large group of patients with pantothenate kinase associated neurodegeneration (PKAN) J Magn Reson Imaging 2012;35:788-794.

8. Hayflick SJ, Westaway SK, Levinson B, et al. Genetic, clinical, and radiographic delineation of hallervorden-spatz syndrome. $\mathrm{N}$ Engl J Med 2003;348:33-40.

9. de Freitas Ribeiro BN, Salata TM, de Oliveira Antunes L, Antunes BS. Pantothenate kinase associated neurodegeneration in two brothers. Acta Med Port 2015;28:674.

10. Dashti M, Chitsaz A. Hallervorden-spatz disease. Adv Biomed Res 3:191.

11. Alberca R, Rafel E, Chinchon I, Vadillo J, Navarro A. Late onset parkinsonian syndrome in Hallervorden-Spatz disease. J Neurol Neurosurg Psychiatr 1987;50:1665-1668. 